\title{
Increased susceptibility of human endothelial cells to infections by SARS-CoV-2 variants
}

\author{
Julian U. G. Wagner ${ }^{1,3,4} \cdot$ Denisa Bojkova ${ }^{2} \cdot$ Mariana Shumliakivska $^{1} \cdot$ Guillermo Luxán $^{1,3,4}{ }^{(\mathbb{D}} \cdot$ Luka Nicin $^{1}$. \\ Galip S. Aslan ${ }^{1} \cdot$ Hendrik Milting $^{5}$. Joshua D. Kandler ${ }^{2} \cdot$ Andreas Dendorfer $^{3,6} \cdot$ Andreas W. Heumueller $^{1,4}$. \\ Ingrid Fleming ${ }^{3,4,7}$. Sofia-Iris Bibli ${ }^{3,4,7} \cdot$ Tobias Jakobi $^{8} \cdot$ Christoph Dieterich $^{3,9} \cdot$ Andreas M. Zeiher $^{3,4,10}$. \\ Sandra Ciesek ${ }^{2,11,12} \cdot$ Jindrich Cinat| $^{2} \cdot$ Stefanie Dimmeler ${ }^{1,3,4} \mathbb{C}$
}

Received: 23 December 2020 / Accepted: 1 June 2021 / Published online: 5 July 2021

(c) The Author(s) 2021

\begin{abstract}
Coronavirus disease 2019 (COVID-19) spawned a global health crisis in late 2019 and is caused by the novel coronavirus SARS-CoV-2. SARS-CoV-2 infection can lead to elevated markers of endothelial dysfunction associated with higher risk of mortality. It is unclear whether endothelial dysfunction is caused by direct infection of endothelial cells or is mainly secondary to inflammation. Here, we investigate whether different types of endothelial cells are susceptible to SARS-CoV-2. Human endothelial cells from different vascular beds including umbilical vein endothelial cells, coronary artery endothelial cells (HCAEC), cardiac and lung microvascular endothelial cells, or pulmonary arterial cells were inoculated in vitro with SARSCoV-2. Viral spike protein was only detected in HCAECs after SARS-CoV-2 infection but not in the other endothelial cells tested. Consistently, only HCAEC expressed the SARS-CoV-2 receptor angiotensin-converting enzyme 2 (ACE2), required for virus infection. Infection with the SARS-CoV-2 variants B.1.1.7, B.1.351, and P.2 resulted in significantly higher levels of viral spike protein. Despite this, no intracellular double-stranded viral RNA was detected and the supernatant did not contain infectious virus. Analysis of the cellular distribution of the spike protein revealed that it co-localized with endosomal calnexin. SARS-CoV-2 infection did induce the ER stress gene EDEM1, which is responsible for clearance of misfolded proteins from the ER. Whereas the wild type of SARS-CoV-2 did not induce cytotoxic or pro-inflammatory effects, the variant B.1.1.7 reduced the HCAEC cell number. Of the different tested endothelial cells, HCAECs showed highest viral uptake but did not promote virus replication. Effects on cell number were only observed after infection with the variant B.1.1.7, suggesting that endothelial protection may be particularly important in patients infected with this variant.
\end{abstract}

Keywords Endothelial cells $\cdot$ SARS-CoV-2 $\cdot$ Virus trapping $\cdot$ ER stress

$\begin{array}{ll}\text { Abbreviations } \\ \text { ACE2 } & \text { Angiotensin-converting enzyme 2 } \\ \text { D-HPAEC } & \begin{array}{l}\text { Human lung pulmonary arterial cells } \\ \text { isolated from diabetics }\end{array}\end{array}$

Julian U. G. Wagner and Denisa Bojkova contributed equally to this work.

Jindrich Cinatl and Stefanie Dimmeler contributed equally to this work.

A comment to this article is available at https://doi.org/10.1007/ s00395-021-00883-7.

Stefanie Dimmeler

dimmeler@em.uni-frankfurt.de

Extended author information available on the last page of the article
ER Endoplasmic reticulum

IFN Interferon

HCAEC Human coronary artery endothelial cells

HCMVEC Human cardiac microvascular endothelial cells

HLMVEC Human lung microvascular endothelial cells

HUVEC Human umbilical venous endothelial cells NRP1 Neuropilin-1

SARS-CoV-2 Severe acute respiratory syndrome coronavirus 2 


\section{Introduction}

Severe acute respiratory syndrome coronavirus 2 (SARSCoV-2) causes the coronavirus disease 2019 (COVID19) that in the last year gave rise to a global pandemic. SARS-CoV-2 primarily invades alveolar epithelial cells and causes acute respiratory distress syndrome. However, increasing evidence indicates that endothelial cell dysfunction and vascular events are major complications of the disease. Indeed, vascular inflammation, barrier defects leading to tissue edema, activation of disseminated intravascular coagulation and microthrombi were reported in moderate to severe COVID-19 cases $[3,8,14,16,27,28$, 30]. In addition, pre-existing impaired endothelial function, i.e., in diabetes mellitus patients and underlying vascular pathologies were shown to worsen clinical outcome of COVID-19 [3, 8, 14, 16, 27, 28, 30]. Whether vascular complications can be attributed to a systemic inflammatory response or are a direct consequence of the viral infection of endothelial cells is currently under debate. To-date, SARS-CoV-2 has been reported to directly infect vascular organoids in vitro [19] and first case studies reported endothelial infection in glomerular capillary loops, skin lesions $[8,10,30]$, as well as provided evidences for endotheliitis in COVID-19 patients [17, 30]. However, the expression of the putative SARS-CoV-2 receptor, i.e., angiotensin-converting enzyme 2 (ACE2) is low in endothelial cells compared to mural cells and recent studies suggest that endothelial cells may not be the primary target of SARS-CoV-2 in the vascular wall [11]. This would imply that the endothelium might be affected independently of direct viral action during the course of the disease, whereby the cytokine storm syndrome associated with elevated levels of pro-inflammatory cytokines such as IL-1 $\beta$, IL-6, and TNF $\alpha$ may cause the loss of antithrombotic and anti-inflammatory functions of endothelial cells $[23,28]$.

To gain insight into whether endothelial cells are a primary target of SARS-CoV-2, we studied human endothelial cells derived from several different vascular beds in vitro.

\section{Materials and methods}

\section{Cells and cardiac tissues}

Human umbilical vein endothelial cells (HUVEC; CC-2935), human coronary artery endothelial cells (HCAEC; CC-2585), human cardiac microvascular endothelial cells (HCMVEC; CC-7030), and human lung microvascular endothelial cells (HLMVEC; CC-2527), and human pulmonary arterial cells isolated from diabetics (D-HPAEC; CC-2924) were purchased from Lonza and cultured in endothelial basal medium (EBM; CC-3156, Lonza) supplemented with $10 \%$ fetal calf serum (FCS; 4133, Invitrogen), amphotericin-B, ascorbic acid, bovine brain extract, endothelial growth factor, gentamycin sulfate, and hydrocortisone (EGM-Bullet Kit; CC-3124, Lonza) or EBM-2 supplemented with $10 \%$ FCS, hydrocortisone, FGF, VEGF, R3-IGF, ascorbic acid, EGF and GA-1000 (EGM-2-Bullet kit; CC-3162, Lonza) at humidified atmosphere, at $37{ }^{\circ} \mathrm{C} / 5 \% \mathrm{CO}_{2}$.

Primary human umbilical vein endothelial cells were isolated and purified using CD144 antibody-coated magnetic beads (Dynal Biotech, Hamburg, Germany) and cultured as reported previously [6]. The human umbilical cords were obtained from local hospitals in Frankfurt am Main and the use of human material in this study conforms to the principles outlined in the Declaration of Helsinki. The isolation of human cells was approved by the ethics committee at the Goethe University in Frankfurt am Main. HUVEC were cultured in endothelial basal medium (EBM; CC-3156, Lonza) as mentioned above for the commercial HUVEC.

Living human heart slices were generated and cultured as recently described [9]. Samples of left ventricular myocardium were obtained from failing hearts during transplantation in the Clinic of Thoracic and Cardiovascular Surgery, Heart and Diabetes Center, Bad Oeynhausen, Germany. The procedure has been approved by the institutional ethics board, and patients have provided informed consent to the scientific use of the explanted tissue. In brief, heart slices were generated from the explanted failing human myocardium by cutting $300-\mu \mathrm{m}$-thick vibratome sections. Slices were mounted and cultured in biomimetic culture chambers in a standard incubator $\left(37{ }^{\circ} \mathrm{C}, 5 \% \mathrm{CO}_{2}, 20 \% \mathrm{O}_{2}, 80 \%\right.$ humidity) [9]. Pacing was performed at $0.5 \mathrm{~Hz}$ with bipolar $50 \mathrm{~mA}$ pulses comprised of $1 \mathrm{~ms}$ charging and discharging pulses separated by a $1 \mathrm{~ms}$ interval. Slices were cultured in Medium 199 supplemented with penicillin/streptomycin, insulin/transferrin/selenite and $50 \mu \mathrm{M}$ 2-Mercaptoethanol. Medium was exchanged in part (1.6 $\mathrm{ml}$ of $2.4 \mathrm{ml}$ total volume in each biomimetic cultivation chamber) at $36-48 \mathrm{~h}$ intervals.

\section{Infection}

SARS-CoV-2 (strains: D614, G614, B.1.1.7, B.1.351, and P.2) were isolated and propagated in $\mathrm{CaCo} 2$ cells as previously described $[4,12]$. For infection of endothelial cells, the viral stock was diluted to the desired MOI (multiplicity of infection) in the respective medium supplemented with $1 \%$ FCS and incubated for $2 \mathrm{~h}$. Then, the medium was changed to the respective culture media (see above). Five days after 
infection, endothelial cells were fixed in 4\% paraformaldehyde (PFA) for 10 min or lysed for RNA isolation. $\mathrm{CaCo} 2$ cells were fixed after $24 \mathrm{~h}$. Living human heart slices were incubated with $200 \mu \mathrm{l}$ of viral stock $\left(1.10^{7}\right.$ TCID 50/ml) for 3-5 days using the above-mentioned medium without 2-Mercaptoethanol.

For experiments that mimic pro-inflammatory conditions, endothelial cells were treated for $24 \mathrm{~h}$ with $30 \mathrm{ng} / \mathrm{ml} \mathrm{TNF} \alpha$ (210-TA-005, R\&D Systems), 10 ng/ml IFN $\beta$ (8499-IF-010, R\&D Systems) or $10 \mathrm{ng} / \mathrm{ml}$ IFN $\gamma$ (285-IF-100, R\&D Systems) prior to viral infection.

To block proteasomal degradation, cells were incubated with the virus together with $10 \mu$ M MG132 (M7449, SigmaAldrich; solved in DMSO) for $24 \mathrm{~h}$.

To inhibit viral infection, HCAECs pre-incubated with $10 \mu \mathrm{M}$ chloroquine (PHR1258, Sigma-Aldrich), $1 \mu \mathrm{M}$ (in DMSO) cathepsin inhibitor $N$-Acetyl-L-leucyl-L-leucyl-Lmethional (ALLM; 0384, Tocris) or $20 \mu \mathrm{M}$ Furin Inhibitor I (344390-AMG, Merck). $5 \mu \mathrm{g} / \mathrm{ml}$ human recombinant ACE2 (933-ZN, R\&D Systems) was mixed with the virus and incubated for $30 \mathrm{~min}$, prior to infection. Cells were fixed 3 days after infection.

\section{Immunofluorescence labeling}

Cells were fixed with 4\% PFA and were permeabilized with $0.1 \%$ Triton X-100/PBS for $10 \mathrm{~min}$. Cells were blocked with blocking solution (5\% donkey serum in PBS) for $1 \mathrm{~h}$ at RT. Primary antibodies were incubated in blocking solution overnight at $4{ }^{\circ} \mathrm{C}$. After four 5-min washes with PBS, secondary antibodies and DAPI were incubated for $1 \mathrm{~h}$ in blocking solution. Finally, two 5-min washes of PBS were performed before cell observation.

Heart slices were fixed in 4\% HistoFix (P087.4, Carl Roth $\mathrm{GmbH}$ ) for $24 \mathrm{~h}$ at $4{ }^{\circ} \mathrm{C}$. Slices were transferred to a series of ascending sucrose concentration: $4 \%$ sucrose in PBS $\left(1 \mathrm{~h}, 4{ }^{\circ} \mathrm{C}\right), 15 \%$ sucrose in PBS $\left(4 \mathrm{~h}, 4^{\circ} \mathrm{C}\right)$ and finally $30 \%$ sucrose in PBS (overnight, $4{ }^{\circ} \mathrm{C}$ ). The day after, slices were washed twice for $30 \mathrm{~min}$ with $100 \mathrm{mM}$ glycine at $4{ }^{\circ} \mathrm{C}$ and once with PBS for $30 \mathrm{~min}$ at $4{ }^{\circ} \mathrm{C}$. Cardiac slices were permeabilized with $1 \%$ Triton X-100 in PBS overnight at $4{ }^{\circ} \mathrm{C}$. Slices were then washed three times with PBS for 30 min at $4{ }^{\circ} \mathrm{C}$ and blocked with blocking solution $(3 \%$ BSA in $0.3 \%$ Triton X-100) overnight at $4{ }^{\circ} \mathrm{C}$. Slices were washed three times in $0.3 \%$ Triton $\mathrm{X}-100$ and incubated with primary antibodies that were diluted in blocking solution (overnight, $4{ }^{\circ} \mathrm{C}$ ). Slices were again washed trice with $0.3 \%$ Triton X-100/PBS (30 min each) and incubated with the secondary antibodies that were diluted in PBS (overnight, $4{ }^{\circ} \mathrm{C}$ ). Finally, slices were again washed trice with $0.3 \%$ Triton X-100/PBS before mounting (see Suppl. Tab. 1 for detailed antibody information).

\section{RT-qPCR and gel electrophoresis}

Total RNA was isolated using RNeasy Mini Kit (217004, Qiagen) according to the manufacturer's instructions including an on-column DNase I digestion step (79254, Qiagen). Reverse transcription was performed using $500 \mathrm{ng}$ RNA, random hexamers and MuLV reverse transcriptase (N8080018, Thermo Fisher). Fast SYBR Green qPCR were carried out by StepOnePlus real-time PCR systems (4385617, Thermo Fisher). RPLP0 amplification was used for data normalization. Relative expression levels were calculated by $2^{-\Delta \mathrm{Ct}}$. Primer sequences are provided in Suppl. Table 2. PCR products were visualized on a $1.5 \%$ agarose gel in 1xTAE buffer and visualized with Midori Green Advance (617004, Biozym Scientific GmbH).

\section{Quantification of virus titer in cell culture supernatants}

Supernatants from infected endothelial cells were collected 5 days post-infection. Confluent layers of $\mathrm{CaCo}_{2}$ cells in 96-well plates were infected with serially diluted supernatants. Cytopathogenic effect (CPE) was assessed visually $48 \mathrm{~h}$ after infection. The infectious titer was determined as TCID50/ml.

\section{Single-nuclei RNA-sequencing analysis}

Single-nuclei RNA-sequencing data from human cardiac samples were derived from a previously published data set [21]. Data were analyzed with the Seurat (v3) package.

\section{Statistical analysis}

Data are represented as mean and error bars indicate standard error of the mean (SEM). Data were statistically assessed for Gaussian distribution using Kolmogorov-Smirnov and Shapiro-Wilk test. For comparison of two groups, statistical power was determined using two-tailed, unpaired $t$ test. For multiple comparisons, ordinary one-way ANOVA with a post hoc Dunnett's or Turkey's multiple comparison was used.

\section{Results}

\section{Infection of different endothelial cells by SARS-CoV-2}

Human umbilical vein endothelial cells (HUVEC), human coronary artery endothelial cells (HCAEC), human cardiac microvascular endothelial cells (HCMVEC) and human lung microvascular endothelial cells (HLMVEC) were incubated 
(a)

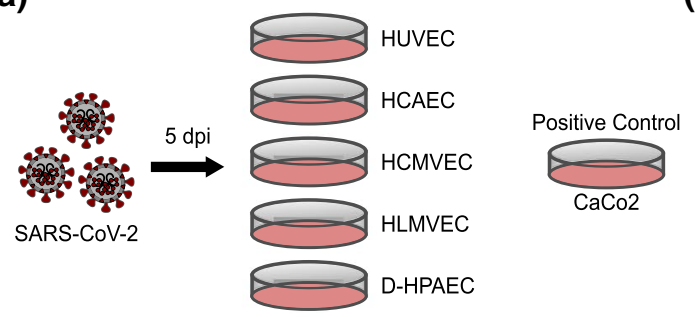

(b)
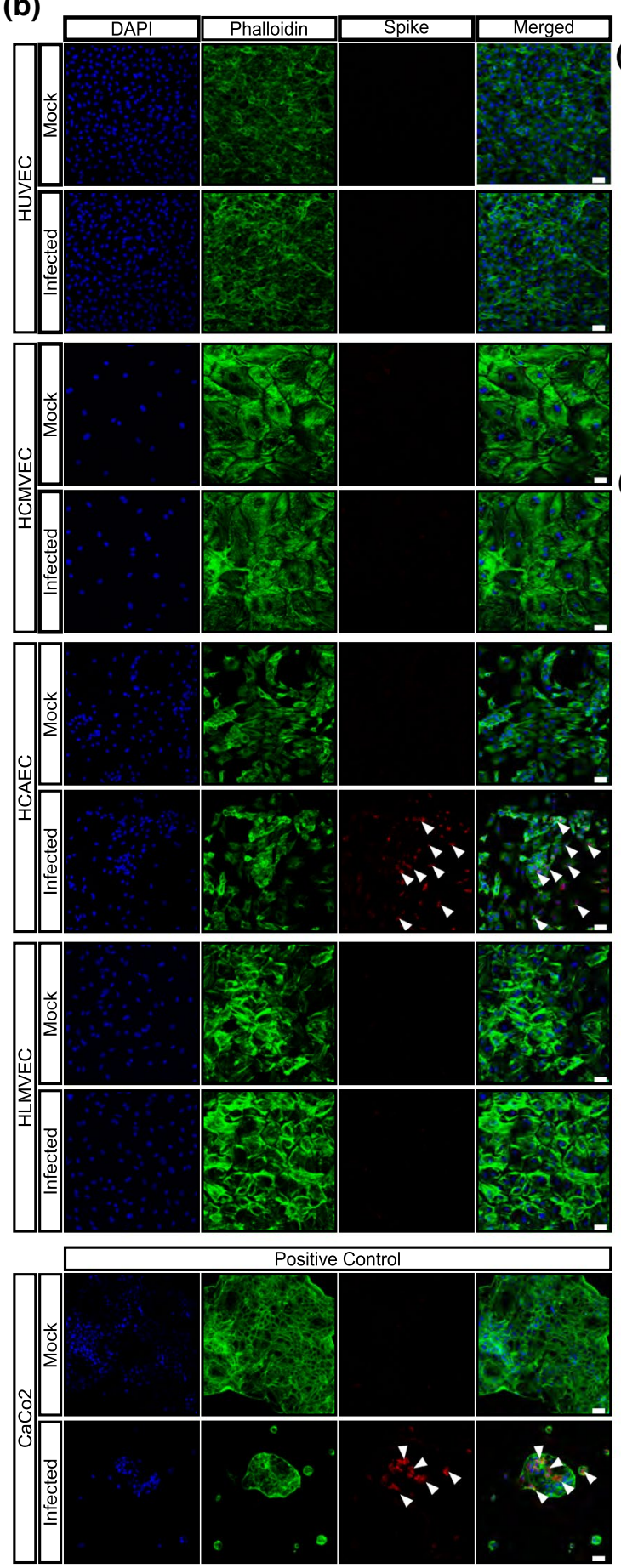

(c)

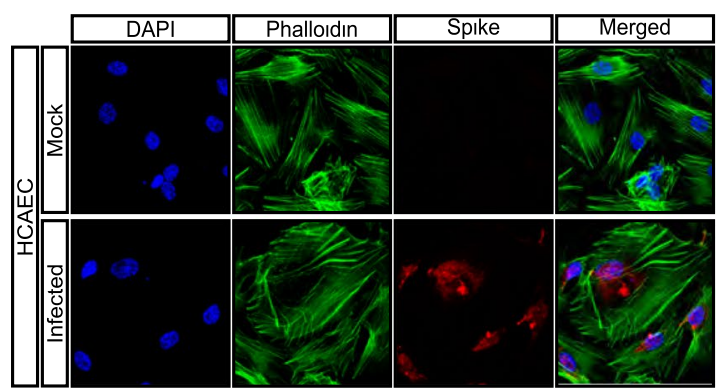

(d)

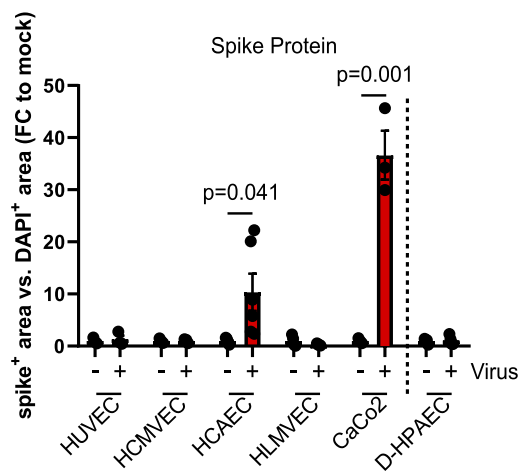

(e)

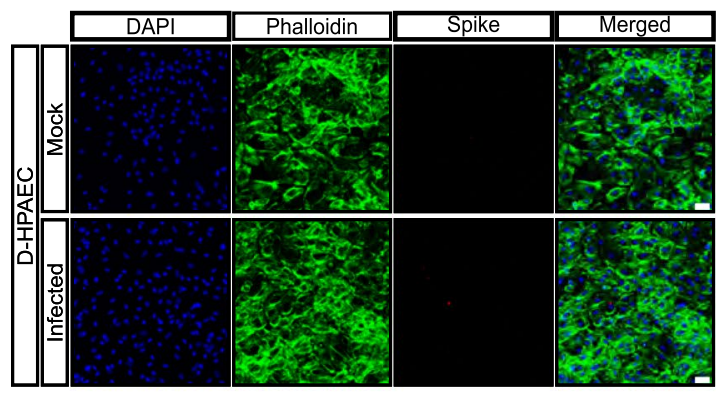

(f)

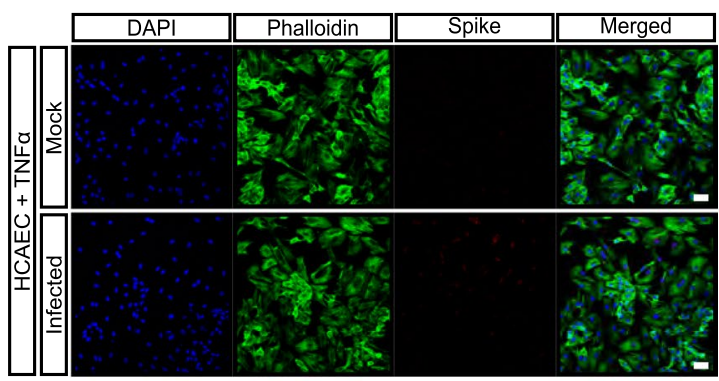

(g)

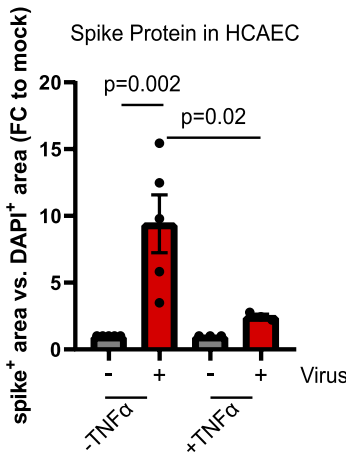

(h) Spike Protein in HCAEC

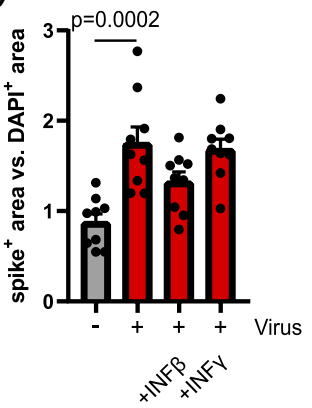


४Fig. 1 Human coronary artery endothelial cells are permissive for SARS-CoV-2. a Schematic experimental setup. b Human umbilical vein endothelial cells (HUVEC), human coronary artery endothelial cells (HCAEC), human cardiac microvascular endothelial cells (HCMVEC), and human lung microvascular endothelial cells (HLMVEC) were commercially purchased and were infected with SARSCoV-2 $(\mathrm{MOI}=1)$ for $2 \mathrm{~h}$. Cells were cultured for 5 days. Human colon carcinoma cells $(\mathrm{CaCo} 2)$ were used as positive control and harvested after 1 day. Spike protein (red) was detected using the rabbitSARS-CoV-2 Spike primary antibody (indicated by white arrows) and cells were counterstained for DAPI (blue) and phalloidin (green). c Representative high magnification image of HCAECs experiments shown in b. d Quantification of data shown in B $(n=6$ for HCAEC, $\mathrm{n}=3$ all other ECs). e Human lung pulmonary arterial cells isolated from diabetics (D-HPAEC) were commercially purchased and were infected with SARS-CoV-2 $(\mathrm{MOI}=1)$ for $2 \mathrm{~h}$. Cells were cultured for 5 days. Spike protein (red) was detected using the rabbit-SARSCoV-2 Spike primary antibody and cells were counterstained for DAPI (blue) and phalloidin (green). $n=3$. f HCAEC were treated with $30 \mathrm{ng} / \mathrm{mL}$ TNF $\alpha$ prior to SARS-CoV-2 inoculation (as described for panel b) $n=3$. Cells were cultured for 5 days. Spike protein (red) was detected using the rabbit-SARS-CoV-2 Spike primary antibody and cells were counterstained for DAPI (blue) and phalloidin (green). $\mathbf{g}$ Quantification of data shown in $\mathbf{b}$ and $\mathbf{f}$. $\mathbf{h}$ HCAEC were infected with SARS-CoV-2 isolates in the presence and absence of $10 \mathrm{ng} /$ $\mathrm{ml}$ human recombinant interferon beta (IFN $\beta$ ) or interferon gamma (IFN $\gamma)$. Cells were cultured for 5 days and fixed with 4\% PFA. Spike protein (red) was detected using the rabbit-SARS-CoV-2 Spike primary antibody (provided by Hölzel) and cells were counterstained for DAPI (blue) and phalloidin (green). Data are shown as mean and error bars indicate the standard error of the mean (SEM). After passing normality tests, data were statistically accessed using an unpaired, two-tailed $T$ test to compare mock treated cells to their respective infected counterpart (d) or using a one-way ANOVA test with a post hoc Turkey's test $(\mathbf{g}, \mathbf{h})$. Scale bars $=50 \mu \mathrm{m}$

with isolated SARS-CoV-2 [4] for $2 \mathrm{~h}$ and viral infection was measured 5 days post-infection by detection of intracellular viral spike protein (Fig. 1a). Spike protein was only weakly detected in HCAEC and not in any of the other endothelial cells (Fig. 1b-d), even when extending the duration of infection to $24 \mathrm{~h}$ (data not shown). The activity of the viral strain used [5] was evidenced by its ability to infect $\mathrm{CaCo} 2$ cells (Fig. 1b, d). Since we used expanded endothelial cell cultures that might change their gene expression during passaging, the ability of the virus to infect freshly isolated HUVEC was also tested. In line with the results obtained with commercially available HUVEC, no viral spike protein could be detected following incubation with SARS-CoV-2 (Suppl. Fig. 1a-c). Of note, endogenous degradation pathways might also prevent significant virus accumulation in HCAEC. To test this assumption, we treated HCAEC with the proteasomal inhibitor MG132. MG132 significantly increased spike protein accumulation suggesting that indeed endogenous degradation pathways limit viral protein accumulation (Suppl. Fig. 2).

Since diabetes mellitus is a risk factor for complicated courses of COVID-19, we additionally infected pulmonary artery endothelial cells from subjects with diabetes (D-HPAEC). However, no spike protein was detected (Fig. 1d, e). In addition, we investigated whether or not a pro-inflammatory environment could sensitize endothelial cells to SARS-CoV-2 infection. To mimic a proinflammatory environment as it would occur in COVID-19 patients, we pre-incubated endothelial cells with TNF- $\alpha$ or interferons for $24 \mathrm{~h}$ prior to infection. However, the preexposure of endothelial cells to TNF- $\alpha$, IFN $\beta$ or IFN $\gamma$ did not change the levels of spike protein in any of the endothelial cells studied (Fig. 1f-h and Suppl. Fig. 2). Rather, the inflammatory cytokine TNF- $\alpha$ reduced spike protein levels in SARS-CoV-2 infected HCAECs (Fig. 1f, g, Suppl. Fig. 3). Given the discussion, that hydrocortisone may be antiviral [17] and given the fact that the used media contain hydrocortisone, we repeated the SARS-CoV-2 infection experiments in hydrocortisone-depleted media. However, no differences in spike detection were found in the presence and absence of hydrocortisone (data not shown).

We additionally explored whether the cardiac microvascular endothelium can be infected in human heart slides ex vivo. However, only cardiomyocytes and other interstitial cells were positive for spike protein (Fig. 2, white arrows). There was no endothelial cell found to be positive for spike protein. Together these data suggest that only coronary artery endothelial cells but, not cardiac microvascular or pulmonary endothelial cells are susceptible to SARS-CoV-2 infection in vitro.

\section{Expression of putative SARS-CoV-2 receptors in human endothelial cells}

Next, we determined whether the different susceptibility of endothelial cell types to SARS-CoV-2 infection might be explained by expression of putative SARS-CoV-2 receptors. The well-established co-receptor ACE2 was expressed by HCAEC but not by any of the other endothelial cells (Fig. 3a, Suppl. Fig. 1a). However, unlike $\mathrm{CaCo} 2$ cells, where ACE2 proteins was concentrated at the cell membrane, in HCAECs ACE2 was largely present in the perinuclear area with little or no protein detectable at the plasma membrane (Fig. 3a, b). Expression of the mRNA encoding the protease TMPRSS2, which was shown to act as an activator of SARS-CoV-2 entry, was below detection level in all of the endothelial cells studied (CT-values of water control: 36 , TMPRSS2: $37.8 \pm 0.7$ in endothelial cells compared to $22 \pm 0.2$ in $\mathrm{CaCo} 2$ cells). Other proteases known to be involved in SARS-CoV-2 uptake, such as cathepsin B and cathepsin L, were expressed in the endothelial cells tested (Fig. 3c). Neuropilin-1 (NRP1) was recently reported to bind to Furin-cleaved substrates and to potentiate SARS-CoV-2 infectivity [7]. NRP1 and FURIN were clearly expressed in heart tissue as determined by single nucleus RNA sequencing (Suppl. Fig. 4) and in all of the cultured endothelial 
Fig. 2 SARS-CoV-2 infection in living human heart slices. Spike protein (red) was detected using the rabbit-SARS-CoV-2 Spike primary antibody (indicated by white arrows) and slices were counterstained for DAPI (blue) and sarcomeric-actin (grey). Shown are one representative image for mock infected slices and two representative images for infected heart slices. Scale bars $=50 \mu \mathrm{m}$
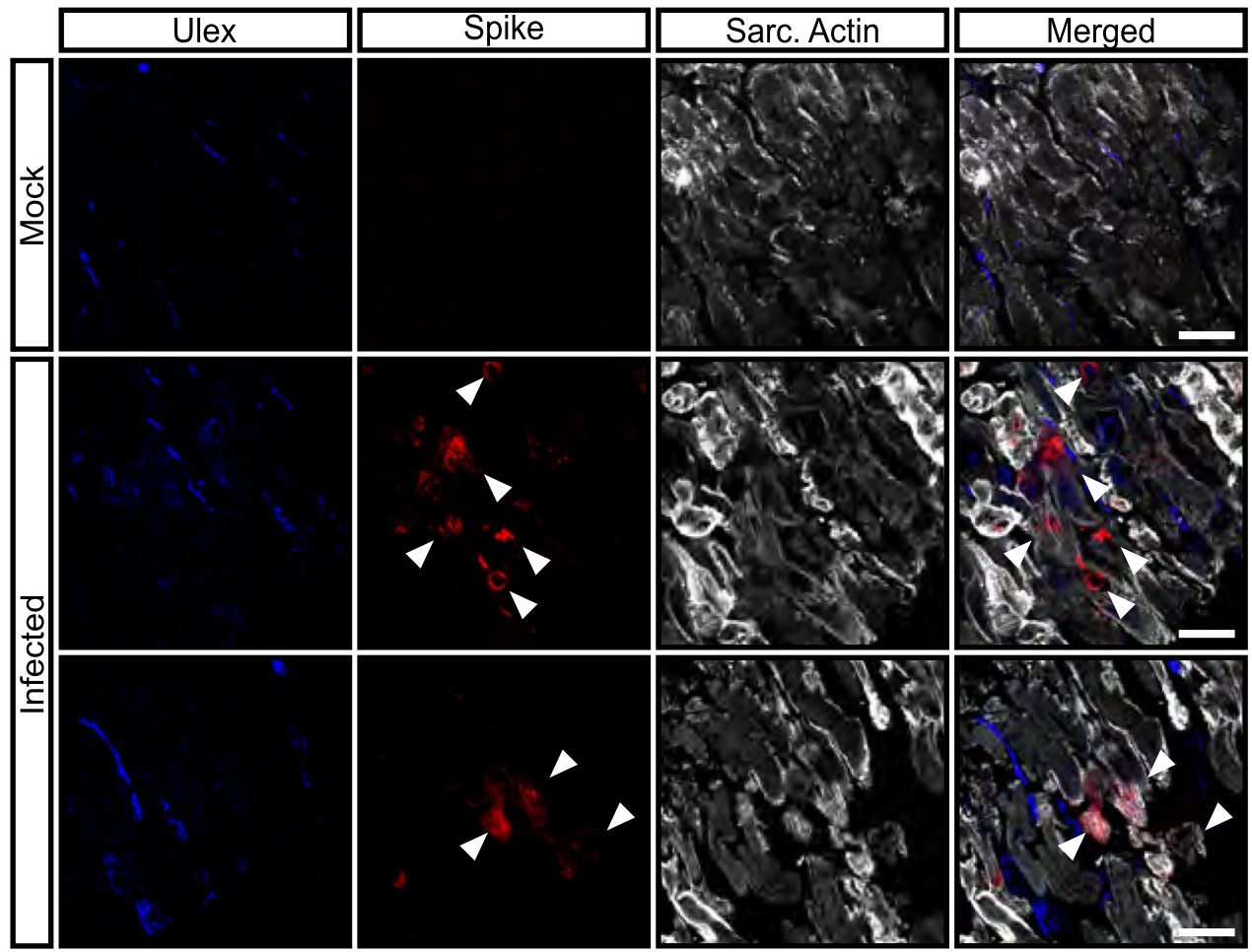

cells (Fig. 3c). CD209L was reported to be a further receptor for SARS-CoV-2 in epithelial and endothelial cells [1], and surprisingly, was weakly expressed by HLMVEC and D-HPAEC only (Fig. 3c). Interestingly, bulk RNA sequencing analysis of human aortic endothelial cells, HCMVEC and HUVEC showed elevated levels of ACE2, CTSL and NRP in aortic endothelial cells, which may explain why arterial or coronary endothelial cells might be more prone to SARS-CoV-2 infection (Suppl. Fig. 5). To assess the involvement of these proteins in SARS-CoV-2 entry, SARSCoV-2 infected HCAECs were co-incubated with human recombinant ACE2, FURIN-inhibitor I, chloroquine and the non-selective cathepsin inhibitor ALLM. Interestingly, 3 days post-infection, we found a significant reduction in spike protein staining under all of these conditions (Fig. 3d).

\section{Effects of SARS-CoV-2 infection on HCAECs}

Although we detected spike protein in HCAECs after SARSCoV-2 infection, this does not necessarily document permissive infection of the endothelial cells. Therefore, we further assessed the levels of double-stranded RNA, as a sign of viral RNA synthesis [25, 29], and the presence of infectious virus in the cell supernatant, which would be indicative of viral replication. However, neither double-strand RNA (Fig. 4a) nor infectious virus in HCAEC supernatant could be detected 5 days after SARS-CoV-2 infection (Fig. 4b, Suppl. Table 3). Intracellular RNA copies were only transiently increased during the initial 3 days (Fig. 4c), suggesting that no new virus is generated by the tested endothelial cells and that the spike protein may originated from the virus that was originally taken up.

Indeed, SARS-CoV-2 has been reported to enter cells via receptor-mediated endocytosis [29], and the spike protein detected in HCAECs was localized to endosomal calnexinpositive areas (Fig. 4d). To determine if endosomal localized virus may elicit an ER stress response, we measured various genes known to be induced by ER stress. Interestingly, only EDEM1, which is involved in the clearance of misfolded proteins [18], was transiently up-regulated at day 1 and day 2 post-infection (Fig. 4e), whereas BiP, DDIT3 and ATF4 mRNA expression were not affected (Fig. 4f-h).

Finally, we assessed putative cytotoxic effects in the SARS-CoV-2-infected endothelial cells. However, we did not find evidence for cytopathic effects in the endothelial cells studied (Fig. 4i, Suppl. Figs. 1d, 3c). Moreover, expression of the inflammatory cytokine IL-6, the adhesion molecule ICAM1 and the pro-angiogenic and permeability inducing VEGF were not changed by SARS-CoV-2 infection. VCAM1 was down-regulated by active and UV-irradiated SARS-CoV-2 virus (Fig. 4j).

\section{Effects of SARS-CoV-2 variants on HCAECs}

Recently, we have isolated and characterized several novel SARS-CoV-2 variants including B.1.1.7 (mutations include N501Y and del69/70), B.1.351 (mutations include E484K and N501Y) and P.2 (mutations include E484K in the 
(a)

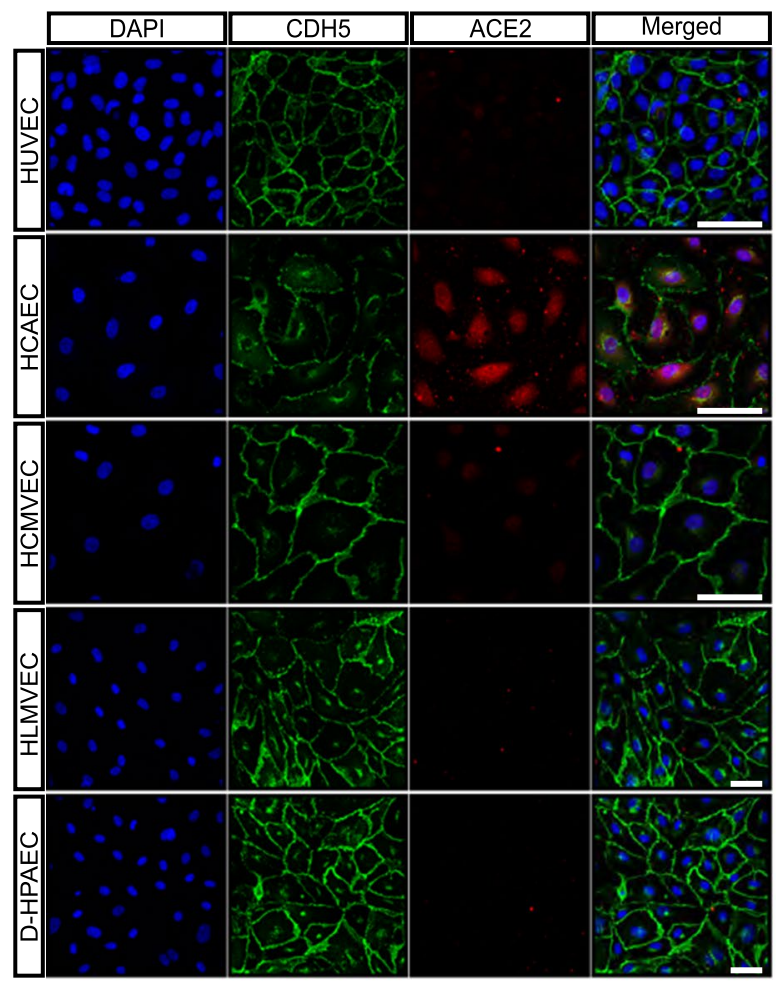

(b)

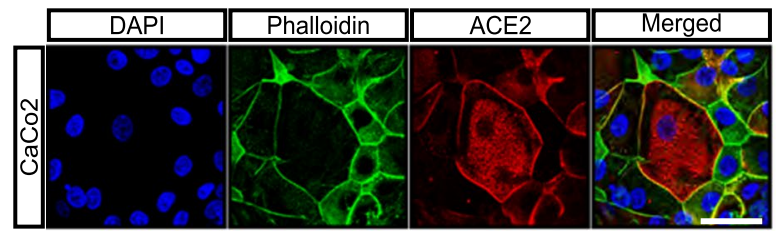

(c)
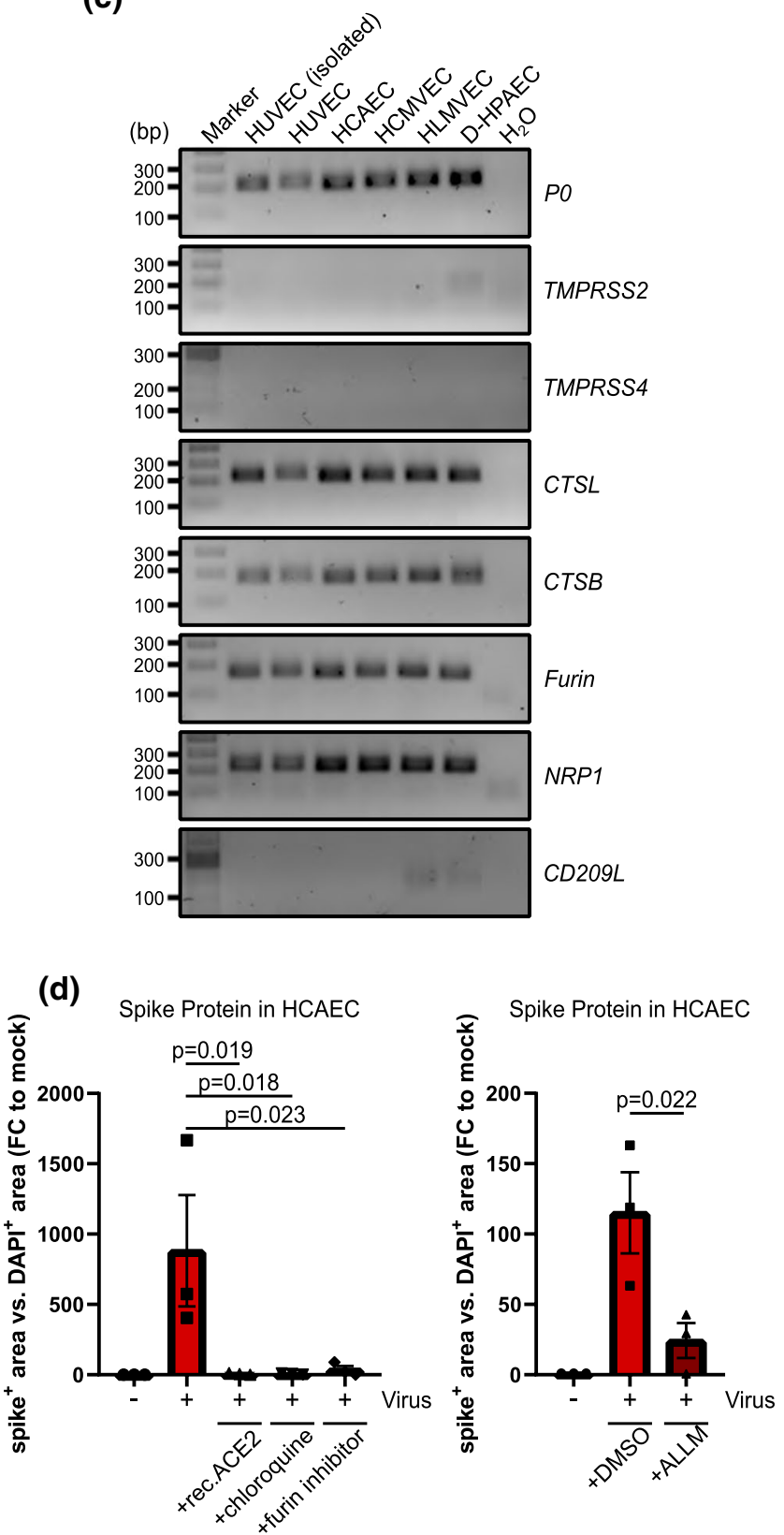

were incubated with $10 \mu \mathrm{M}$ chloroquine, $1 \mu \mathrm{M}$ (in DMSO) cathepsin inhibitor $N$-Acetyl-L-leucyl-L-leucyl-L-methional (ALLM) and $20 \mu \mathrm{M}$ FURIN-inhibitor I. $5 \mu \mathrm{g} / \mathrm{ml}$ of human recombinant ACE2 was mixed with the virus and incubated for $30 \mathrm{~min}$, prior to infection. Cells were fixed and stained against viral spike protein. Experiments were conducted in triplicate. Data are shown as mean and error bars indicate SEM. Data were statistically assessed using a one-way ANOVA test with a post hoc Dunnett's test

HCAECs. Cells were infected with different SARS-CoV-2 variants (D614, G614, B.1.1.7, B.1.351, P.2) at MOI 1. Viral replication was assessed by measurement of viral RNA at different time points post-infection. The production absence of a N501Y mutation) [31]. Emergence of these variants has raised concerns regarding their host infection capability. We have performed comparative experiments to test whether the novel variants may infect and replicate in 
(a)

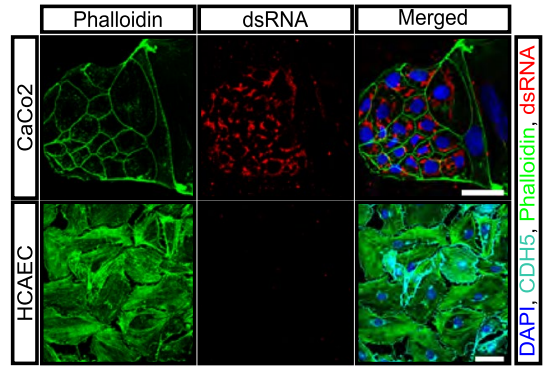

(d)

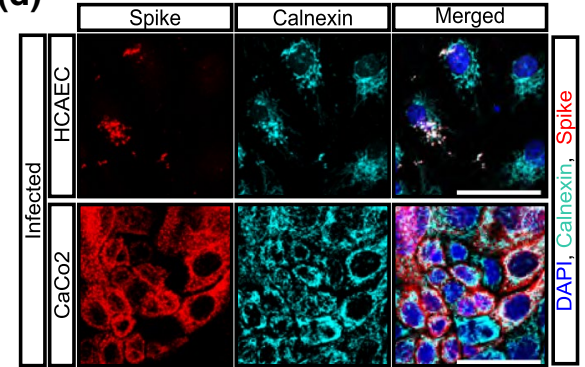

(b)

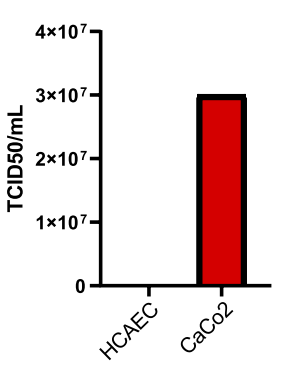

(e)

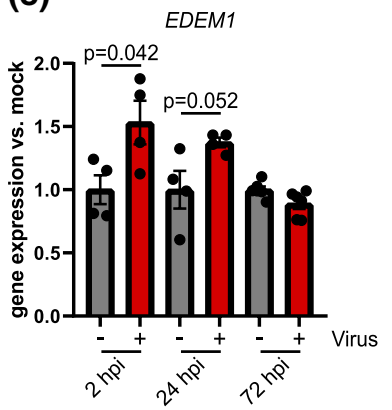

(c) Viral RNA Copies

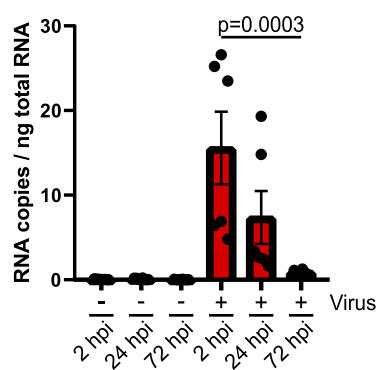

(f)

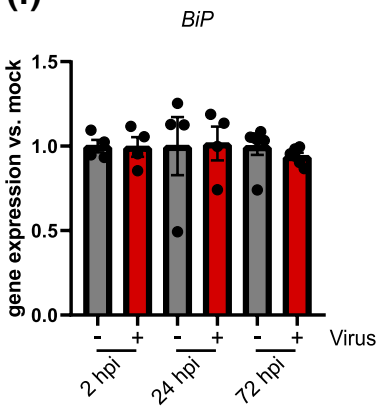

(g)

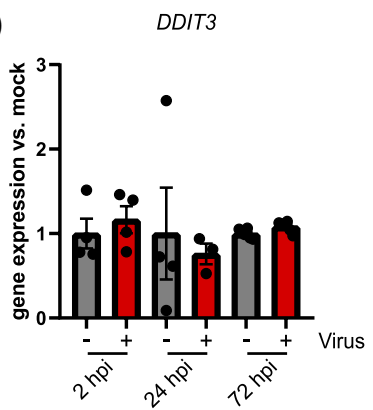

(h)

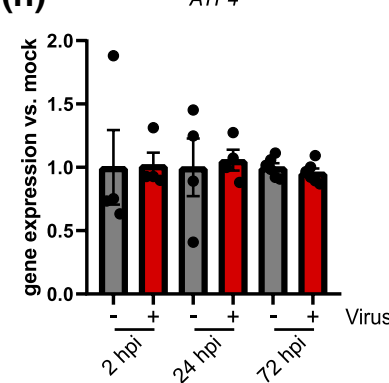

(i)

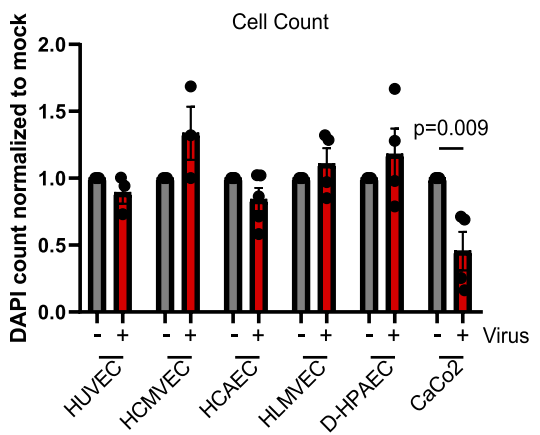

(j)

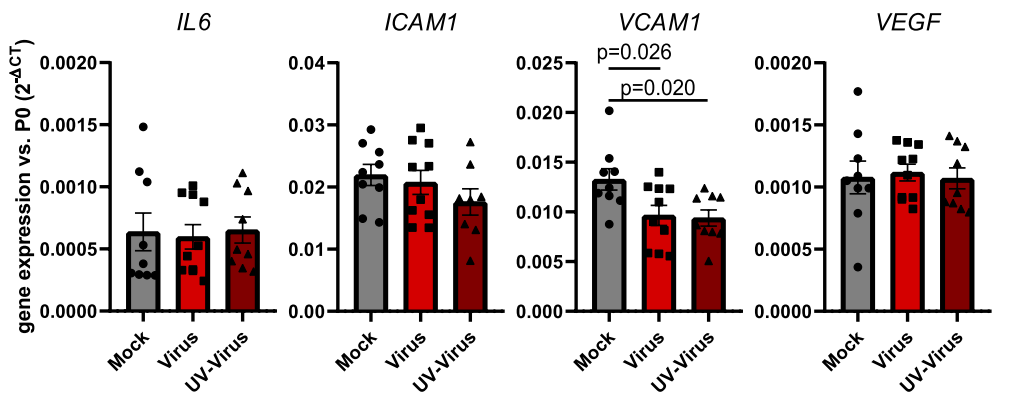

Fig. 4 SARS-CoV-2 does not replicate in HCAEC. a Detection of double-strand viral RNA (red) in infected $\mathrm{CaCo} 2$ cells as positive control (upper panel) and infected HCAEC (lower panel). CDH5 (cyano), Phalloidin (green) and DAPI (blue) served as counterstain. b Infectious virus in supernatants from infected HCAEC and $\mathrm{CaCo} 2$ cells was determined by titration in $\mathrm{CaCo} 2$ cells $48 \mathrm{~h}$ post-infection $n=3$. c Detection of viral RNA copies per ng total RNA lysate in HCAEC $2 \mathrm{~h}, 24 \mathrm{~h}$ and $72 \mathrm{~h}$ post-infection (hpi) $n=3$. d Immunostaining of calnexin (cyano) and spike protein (red) in HCAEC (5 dpi) and $\mathrm{CaCo} 2$ cells $(1 \mathrm{dpi})$. e-h mRNA expression of EDEM1, BiP, DDIT3 and ATF4 in HCAEC $2 \mathrm{~h}, 24 \mathrm{~h}$ and $72 \mathrm{~h}$ post-infection $n=4$
( $2 \mathrm{hpi}, 24 \mathrm{hpi}$ ) and $n=6$ (72 hpi). i DAPI-positive cells were counted in experiments shown in panel $\mathbf{a} n=3$ and $n=6$ (HCAEC). $\mathbf{j}$ mRNA expression of $I L-6, I C A M 1, V C A M 1$ and $V E G F$ was determined by RT-qPCR $n=9$. Data are shown as mean and error bars indicate the standard error of the mean (SEM). After passing normality tests, data were statistically accessed using an unpaired, two-tailed $T$ test to compare mock treated cells to their respective infected counterpart (e-i). To compare more than two groups, data were assessed statistically using one-way ANOVA with a post hoc Dunnett's multiple comparison test $(\mathbf{c}, \mathbf{j})$. Scale bars $=50 \mu \mathrm{m}$ 
of infectious viral particles was determined by titration of infected cell supernatants on confluent $\mathrm{CaCo} 2$ cell layers. Although intracellular viral RNA was detected after infection of HCAECs with the variants, particularly the variant B1.1.7, no increase was observed over time (Fig. 5a), indicating that the virus enters the cell, but does not replicate in the endothelial cells. Consistently, none of the variants produced infectious viral particles (Fig. 5b). These data demonstrate that SARS-CoV-2 variants are not able to replicate in HCAEC. However, we observed enhanced virus uptake in endothelial cells by novel SARS-CoV-2 variants (B.1.1.7, B.1.351, and P.2) in association with increased spike staining compared to early variants (D614 and G614) (Fig. 5c). Interestingly, cell toxicity was not observed, despite B.1.1.7, which significantly reduced HCAEC counts (Fig. 5c).

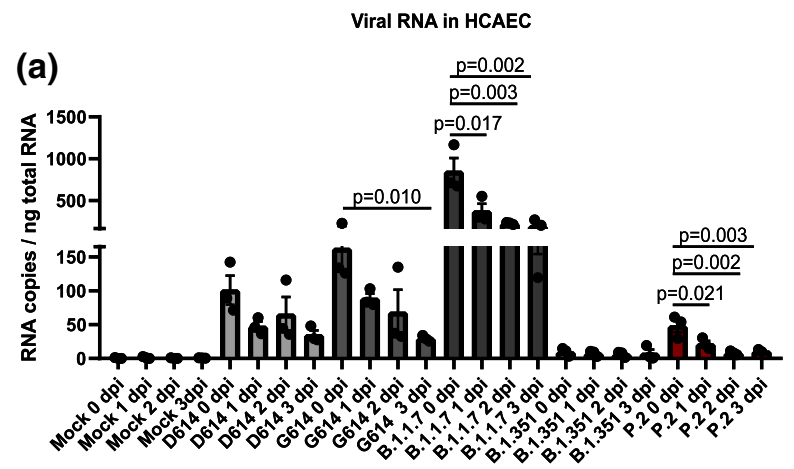

(c)
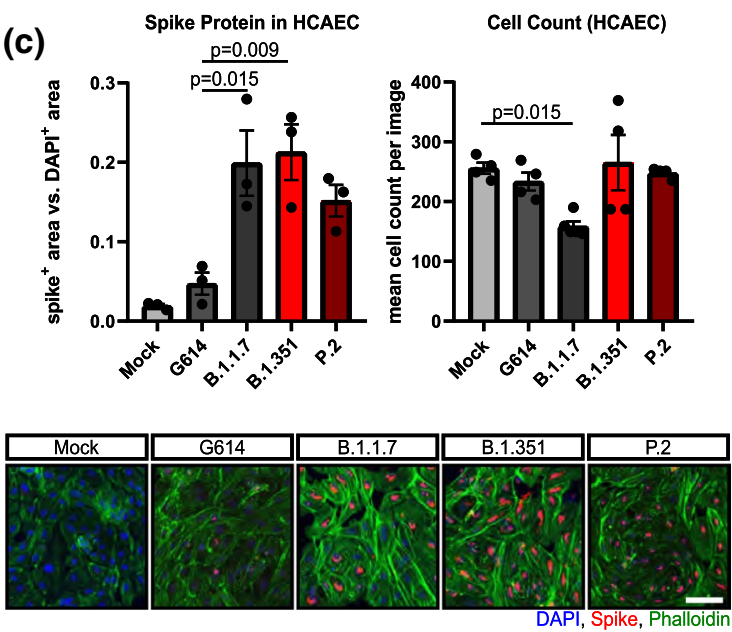

Fig. 5 SARS-CoV-2 variants do not replicate in endothelial cells. a Detection of viral RNA copies per ng total RNA lysate in HCAEC 0 days, 1 day, 2 days and 3 days post-infection (dpi). Two early isolates (D614, G614) as well as the variants B.1.1.7, B.1.351 and P. 2 SARS-CoV-2 variants were used $(n=3)$. b Infectious virus in supernatants from infected HCAEC was determined by titration in $\mathrm{CaCo} 2$ cells $0 \mathrm{~h}$ and $48 \mathrm{~h}$ post-infection (hpi) $n=3$. c Immunostaining of spike protein (red) in HCAEC (5 dpi). DAPI (blue) and Phal-

\section{Discussion}

The results of the current investigation suggest that SARSCoV-2 does not permissively infect microvascular or venous endothelial cells from different sources. However, HCAEC appear to take up the virus and show positive spike protein in the endosomal compartment. Since no permissive infection was detected in endothelial cells, SARS-CoV-2 might indirectly induce endothelial cell dysfunction via the systemic inflammatory response that causes the observed striking vascular effects in patients with COVID-19.

Interestingly, of all the endothelial cells studied only HCAECs were positive for spike protein after SARS-CoV-2 infection, suggesting different responses of endothelial cells derived from different vascular beds. Endothelial cell

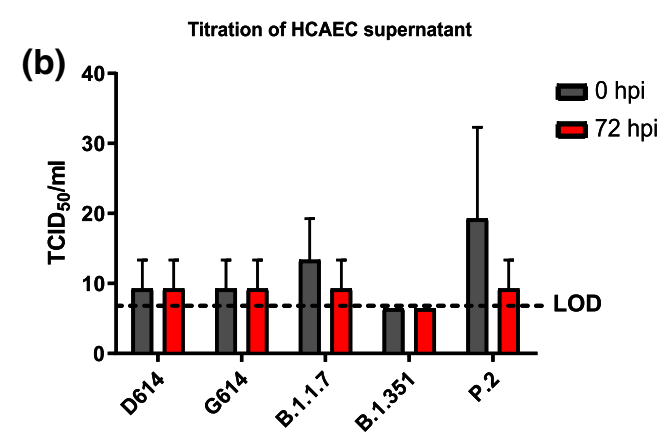

loidin (green) were used as counter staining. HCAEC were infected with one virus isolate D614 as well as the B.1.1.7, B.1.1.7 and P.2 SARS-CoV-2 variant $(n=3)$. Data are shown as mean and error bars indicate the standard error of the mean (SEM) or standard deviation (SD, panel b). After passing normality tests, data were statistically accessed using a one-way ANOVA with a post hoc Turkey's comparison test (b) or post hoc Dunnett's comparison (a, c). Scale bars $=50 \mu \mathrm{m}$ 
heterogeneity and specificity is crucial for the homeostasis of the different organs [2]. In our study, HCAECs show a higher expression of the SARS-CoV-2 receptor ACE2, which may be responsible for mediating the uptake of the virus. HCMVEC, HLMVEC, HUVEC and HPAEC did not express ACE2 and were not permissive for SARS-CoV-2. However, transducing endothelial cells with recombinant ACE2 may enable SARS-CoV-2 infection as shown recently [20], suggesting that the lack of sufficient ACE2 expression might be a limiting factor. Subsequent steps in the viral life cycle appear to be blocked in HCAECs. Since we did not detect double-strand viral RNA in HCAECs upon infection, likely early steps in uncoating of the incoming virus, or endosome-virus membrane fusion, or viral RNA synthesis are haltered in HCAECs. It would be of interest to understand the mechanisms that allow this endothelial cell type to block subsequent virus replication [29]. Interestingly, we observed an early induction of EDEM1, which is known to be involved in clearance of misfolded proteins in the ER [18]. One may speculate that the induction of this gene may be involved in the removal of spike protein limiting further viral activities.

The observation that endothelial cells take up SARSCoV-2 without propagating the virus was also made previously $[22,32]$. However, these studies were performed with stem cell-derived endothelial cells, which may not fully resemble primary cultured lung or cardiac endothelial cells, as used in our study. In addition, one report found no evidence of direct viral infection of vascular endothelial cells in an ex vivo lung culture of one COVID-19 patient [13], which was supported by others [24] and by our own ex vivo heart slice model, where we could not detect spike positive endothelial cells. To our knowledge, this is currently the first study to compare the effect of SARS-CoV-2 variants on endothelial cells. We demonstrate a higher uptake of the three tested virus variants in HCAECs, however, B.1.1.7 was the only variant that affected cell number.

One limitation of the present study and previous reports is that we cannot exclude that endothelial cells in humans might react differently and that the in vitro culture and expansion of endothelial cells change their gene expression and responses. We also tested whether a pro-inflammatory environment would have facilitated virus infection. However, stimulation of endothelial cells with pro-inflammatory cytokines or using endothelial cells cultured from diabetic patients did not augment the SARS-CoV-2 infection in the present in vitro study. Recent findings suggested that inflammatory cytokines contribute to a complicated course of COVID-19 [15]. Therefore, we speculate that pre-treatment of endothelial cells with pro-inflammatory cytokines might sensitize endothelial cells for viral infection. However, we did observe reduced levels of viral spike protein upon TNF $\alpha$ stimulation, whereas IFN $\beta$ and IFN $\gamma$ had no influence. It is unclear why TNF $\alpha$ did reduce viral spike protein load in endothelial cells and limited information is available regarding the effects of TNF $\alpha$ on SARS-CoV-2 virus entry and infection rate. One study reports a link between TNF $\alpha$ and ACE2 expression, which was reduced by systemic anti$\mathrm{TNF} \alpha$ treatment in intestinal cells [26]. However, we did not find a transcriptional regulation of ACE2 in endothelial cells (Suppl. Fig. 6). Thus, one may speculate that TNFo might interfere with other mechanisms resulting in a reduction of viral uptake or destabilization of spike protein.

In conclusion, the lack of a direct cytotoxic or pro-inflammatory effect by SARS-CoV-2 infection of endothelial cells may suggest that the massive endothelial dysfunction and microvascular thrombotic complications observed in patients suffering from COVID-19 is mainly secondarily caused by the inflammatory cascades mediated by the cytokine release syndrome. However, due to reduction of cell number observed after infection of HCAECs with the variant B.1.1.7, patients infected with these SARS-Co-V-2 variants should be closely monitored. Overall, therapeutic interventions aiming at endothelial protection may be warranted to protect against primary or secondary effects to maintain organ integrity during later development of the disease.

Supplementary Information The online version contains supplementary material available at https://doi.org/10.1007/s00395-021-00882-8.

Acknowledgements We thank Lisa-Maria Kettenhausen, Lena Stegmann and Kerstin Euler for experimental assistance and Isabel Winter for isolating HUVEC from umbilical veins. J.W. and D.B. have performed the experiments, J.W. has performed statistical analysis of the data. J.K. has performed qRT-PCR quantification of SARS-CoV-2 variants, G.A., M.S. and G.L. have performed stainings; L.N. has analysed single cell sequencing data; H.M. and A.D. provided human heart slices, A.H., T.J. and C.D. have provided tools and advice regarding ER stress responses, as well as bulk RNA sequencing; I.F. and I.B. has provided primary endothelial cells and contributed to drafting the manuscript; A.M. Zeiher and S. Ciesek have provided conceptual advice, J.C. and S.D. have designed and supervised the study, J.W. and S.D. wrote the manuscript.

Funding Open Access funding enabled and organized by Projekt DEAL. The study is supported by the Deutsche Forschungsgemeinschaft (DFG) (Exc2026-1) (to SD), the Willy Pitzer Foundation (to SC) and Stefan Quandt (to DB).

\section{Declarations}

Conflict of interest The authors declare no conflict of interest.

Open Access This article is licensed under a Creative Commons Attribution 4.0 International License, which permits use, sharing, adaptation, distribution and reproduction in any medium or format, as long as you give appropriate credit to the original author(s) and the source, provide a link to the Creative Commons licence, and indicate if changes were made. The images or other third party material in this article are included in the article's Creative Commons licence, unless indicated otherwise in a credit line to the material. If material is not included in 
the article's Creative Commons licence and your intended use is not permitted by statutory regulation or exceeds the permitted use, you will need to obtain permission directly from the copyright holder. To view a copy of this licence, visit http://creativecommons.org/licenses/by/4.0/.

\section{References}

1. Amraie R, Napoleon MA, Yin W, Berrigan J, Suder E, Zhao G, Olejnik J, Gummuluru S, Muhlberger E, Chitalia V, Rahimi N (2020) CD209L/L-SIGN and CD209/DC-SIGN act as receptors for SARS-CoV-2 and are differentially expressed in lung and kidney epithelial and endothelial cells. bioRxiv

2. Augustin HG, Koh GY (2017) Organotypic vasculature: from descriptive heterogeneity to functional pathophysiology. Science 357:12379. https://doi.org/10.1126/science.aal2379

3. Barbosa LC, Lopes T, de Araujo LP, de Oliveira Rosario LV, Ferrer VP (2021) Endothelial cells and SARS-CoV-2: an intimate relationship. Vascul Pharmacol. https://doi.org/10.1016/j. vph.2021.106829

4. Bojkova D, Klann K, Koch B, Widera M, Krause D, Ciesek S, Cinatl J, Münch C (2020) Proteomics of SARS-CoV-2-infected host cells reveals therapy targets. Nature 583:469-472. https://doi. org/10.1038/s41586-020-2332-7

5. Bojkova D, Wagner JUG, Shumliakivska M, Aslan GS, Saleem U, Hansen A, Luxán G, Günther S, Pham MD, Krishnan J, Harter PN, Ermel UH, Frangakis AS, Milting H, Zeiher AM, Klingel K, Cinatl J, Dendorfer A, Eschenhagen T, Tschöpe C, Ciesek S, Dimmeler S (2020) SARS-CoV-2 infects and induces cytotoxic effects in human cardiomyocytes. Cardiovasc Res 116:2207-2215. https://doi.org/10.1093/cvr/cvaa267

6. Busse R, Lamontagne D (1991) Endothelium-derived bradykinin is responsible for the increase in calcium produced by angiotensinconverting enzyme inhibitors in human endothelial cells. Naunyn Schmiedebergs Arch Pharmacol 344:126-129. https://doi.org/10. 1007/BF00167392

7. Cantuti-Castelvetri L, Ojha R, Pedro LD, Djannatian M, Franz J, Kuivanen S, van der Meer F, Kallio K, Kaya T, Anastasina M, Smura T, Levanov L, Szirovicza L, Tobi A, Kallio-Kokko H, Österlund P, Joensuu M, Meunier FA, Butcher SJ, Winkler MS, Mollenhauer B, Helenius A, Gokce O, Teesalu T, Hepojoki J, Vapalahti O, Stadelmann C, Balistreri G, Simons M (2020) Neuropilin-1 facilitates SARS-CoV-2 cell entry and infectivity. Science 370:856-860. https://doi.org/10.1126/science.abd2985

8. Colmenero I, Santonja C, Alonso-Riaño M, Noguera-Morel L, Hernández-Martín A, Andina D, Wiesner T, Rodríguez-Peralto JL, Requena L, Torrelo A (2020) SARS-CoV-2 endothelial infection causes COVID-19 chilblains: histopathological, immunohistochemical and ultrastructural study of seven paediatric cases. $\mathrm{Br}$ J Dermatol 183:729-737. https://doi.org/10.1111/bjd.19327

9. Fischer C, Milting H, Fein E, Reiser E, Lu K, Seidel T, Schinner C, Schwarzmayr T, Schramm R, Tomasi R, Husse B, CaoEhlker X, Pohl U, Dendorfer A (2019) Long-term functional and structural preservation of precision-cut human myocardium under continuous electromechanical stimulation in vitro. Nat Commun 10:117. https://doi.org/10.1038/s41467-018-08003-1

10. Gambichler T, Reuther J, Stücker M, Stranzenbach R, TorresReyes C, Schlottmann R, Schmidt WE, Hayajneh R, Sriram A, Becker JC (2020) SARS-CoV-2 spike protein is present in both endothelial and eccrine cells of a chilblain-like skin lesion. J Eur Acad Dermatol Venereol. https://doi.org/10.1111/jdv.16970

11. He L, Mäe M, Sun Y, Muhl L, Nahar K, Liébanas E, Fagerlund M, Oldner A, Liu J, Genové G, Pietilä R, Zhang L, Xie Y, Leptidis S, Mocci G, Stritt S, Osman A, Betsholtz C (2020) Pericyte-specific vascular expression of SARS-CoV-2 receptor ACE2-implications for microvascular inflammation and hypercoagulopathy in COVID-19 patients. BioRxiv. https://doi.org/10.1261/rna.18044 10

12. Hoehl S, Rabenau H, Berger A, Kortenbusch M, Cinatl J, Bojkova D, Behrens P, Böddinghaus B, Götsch U, Naujoks F, Neumann P, Schork J, Tiarks-Jungk P, Walczok A, Eickmann M, Vehreschild MJGT, Kann G, Wolf T, Gottschalk R, Ciesek S (2020) Evidence of SARS-CoV-2 infection in returning travelers from Wuhan, China. N Engl J Med 382:1278-1280

13. Hui KPY, Cheung M-C, Perera RAPM, Ng K-C, Bui CHT, Ho JCW, Ng MMT, Kuok DIT, Shih KC, Tsao S-W, Poon LLM, Peiris M, Nicholls JM, Chan MCW (2020) Tropism, replication competence, and innate immune responses of the coronavirus SARSCoV-2 in human respiratory tract and conjunctiva: an analysis in ex-vivo and in-vitro cultures. Lancet Respir Med 8:687-695. https://doi.org/10.1016/S2213-2600(20)30193-4

14. Jin Y, Ji W, Yang H, Chen S, Zhang W, Duan G (2020) Endothelial activation and dysfunction in COVID-19: from basic mechanisms to potential therapeutic approaches. Signal Transduct Target Ther 5:293. https://doi.org/10.1038/s41392-020-00454-7

15. Karki R, Sharma BR, Tuladhar S, Williams EP, Zalduondo L, Samir P, Zheng M, Sundaram B, Banoth B, Malireddi RKS, Schreiner P, Neale G, Vogel P, Webby R, Jonsson CB, Kanneganti T-D (2021) Synergism of TNF- $\alpha$ and IFN- $\gamma$ triggers inflammatory cell death, tissue damage, and mortality in SARS-CoV-2 infection and cytokine shock syndromes. Cell 184:149-168.e17. https://doi. org/10.1016/j.cell.2020.11.025

16. Maccio U, Zinkernagel AS, Shambat SM, Zeng X, Cathomas G, Ruschitzka F, Schuepbach RA, Moch H, Varga Z (2021) SARS$\mathrm{CoV}-2$ leads to a small vessel endotheliitis in the heart. EBioMedicine 63:103182. https://doi.org/10.1016/j.ebiom.2020.103182

17. Matsuyama S, Kawase M, Nao N, Shirato K, Ujike M, Kamitani W, Shimojima M, Fukushi S (2020) The inhaled steroid ciclesonide blocks SARS-CoV-2 RNA replication by targeting the viral replication-transcription complex in cultured cells. J Virol 95:e01648-e1720. https://doi.org/10.1128/JVI.01648-20

18. Molinari M, Calanca V, Galli C, Lucca P, Paganetti P (2003) Role of EDEM in the release of misfolded glycoproteins from the calnexin cycle. Science 299:1397-1400. https://doi.org/10.1126/ science. 1079474

19. Monteil V, Kwon H, Prado P, Hagelkrüys A, Wimmer RA, Stahl M, Leopoldi A, Garreta E, Hurtado Del Pozo C, Prosper F, Romero JP, Wirnsberger G, Zhang H, Slutsky AS, Conder R, Montserrat N, Mirazimi A, Penninger JM (2020) Inhibition of SARS-CoV-2 infections in engineered human tissues using clinical-grade soluble human ACE2. Cell 181:905-913.e7. https://doi. org/10.1016/j.cell.2020.04.004

20. Nascimento Conde J, Schutt WR, Gorbunova EE, Mackow ER (2020) Recombinant ACE2 expression is required for SARS-CoV-2 to infect primary human endothelial cells and induce inflammatory and procoagulative responses. MBio 11:e03185-e3220. https://doi.org/10.1128/mBio.03185-20

21. Nicin L, Abplanalp WT, Mellentin H, Kattih B, Tombor L, John D, Schmitto JD, Heineke J, Emrich F, Arsalan M, Holubec T, Walther T, Zeiher AM, Dimmeler S (2020) Cell type-specific expression of the putative SARS-CoV-2 receptor ACE2 in human hearts. Eur Heart J 41:1804-1806. https://doi.org/10.1093/eurhe artj/ehaa311

22. Pérez-Bermejo JA, Kang S, Rockwood SJ, Simoneau CR, Joy DA, Ramadoss GN, Silva AC, Flanigan WR, Li H, Nakamura K, Whitman JD, Ott M, Conklin BR, McDevitt TC (2020) SARS-CoV-2 infection of human iPSC-derived cardiac cells predicts novel cytopathic features in hearts of COVID-19 patients. BioRxiv. https:// doi.org/10.1101/2020.08.25.265561 
23. Pons S, Fodil S, Azoulay E, Zafrani L (2020) The vascular endothelium: the cornerstone of organ dysfunction in severe SARS-CoV-2 infection. Crit Care 24:353. https://doi.org/10.1186/ s13054-020-03062-7

24. Schaefer I-M, Padera RF, Solomon IH, Kanjilal S, Hammer MM, Hornick JL, Sholl LM (2020) In situ detection of SARS-CoV-2 in lungs and airways of patients with COVID-19. Mod Pathol 33:2104-2114. https://doi.org/10.1038/s41379-020-0595-z

25. Son K-N, Liang Z, Lipton HL (2015) Double-stranded RNA is detected by immunofluorescence analysis in RNA and DNA virus infections, including those by negative-stranded RNA viruses. J Virol 89:9383-9392. https://doi.org/10.1128/JVI.01299-15

26. Suárez-Fariñas M, Tokuyama M, Wei G, Huang R, Livanos A, Jha D, Levescot A, Irizar H, Kosoy R, Cording S, Wang W, Losic B, Ungaro RC, Di'Narzo A, Martinez-Delgado G, Suprun M, Corley MJ, Stojmirovic A, Houten SM, Peters L, Curran M, Brodmerkel C, Perrigoue J, Friedman JR, Hao K, Schadt EE, Zhu J, Ko HM, Cho J, Dubinsky MC, Sands BE, Ndhlovu L, Cerf-Bensusan N, Kasarskis A, Colombel J-F, Harpaz N, Argmann C, Mehandru S (2021) Intestinal inflammation modulates the expression of ACE2 and TMPRSS 2 and potentially overlaps with the pathogenesis of SARS-CoV-2-related disease. Gastroenterology 160:287-301.e20. https://doi.org/10.1053/j.gastro.2020.09.029

27. Tang N, Li D, Wang X, Sun Z (2020) Abnormal coagulation parameters are associated with poor prognosis in patients with novel coronavirus pneumonia. J Thromb Haemost 18:844-847. https://doi.org/10.1111/jth.14768
28. Teuwen L-A, Geldhof V, Pasut A, Carmeliet P (2020) COVID-19: the vasculature unleashed. Nat Rev Immunol 20:389-391. https:// doi.org/10.1038/s41577-020-0343-0

29. Vkovski P, Kratzel A, Steiner S, Stalder H, Thiel V (2020) Coronavirus biology and replication: implications for SARS-CoV-2. Nat Rev Microbiol. https://doi.org/10.1038/s41579-020-00468-6

30. V'arga Z, Flammer AJ, Steiger P, Haberecker M, Andermatt R, Zinkernagel AS, Mehra MR, Schuepbach RA, Ruschitzka F, Moch H (2020) Endothelial cell infection and endotheliitis in COVID-19. Lancet 395:1417-1418. https://doi.org/10.1016/ S0140-6736(20)30937-5

31. Widera M, Wilhelm A, Hoehl S, Pallas C, Kohmer N, Wolf T, Rabenau HF, Corman V, Drosten C, Vehreschild MJGT, Goetsch U, Gottschalk R, Ciesek S (2021) Bamlanivimab does not neutralize two SARS-CoV-2 variants carrying E484K in vitro. MedRxiv. https://doi.org/10.1101/2021.02.24.21252372

32. Yang L, Han Y, Nilsson-Payant BE, Gupta V, Wang P, Duan X, Tang X, Zhu J, Zhao Z, Jaffré F, Zhang T, Kim TW, Harschnitz O, Redmond D, Houghton S, Liu C, Naji A, Ciceri G, Guttikonda S, Bram Y, Nguyen D-HT, Cioffi M, Chandar V, Hoagland DA, Huang Y, Xiang J, Wang H, Lyden D, Borczuk A, Chen HJ, Studer L, Pan FC, Ho DD, tenOever BR, Evans T, Schwartz RE, Chen S (2020) A human pluripotent stem cell-based platform to study SARS-CoV-2 tropism and model virus infection in human cells and organoids. Cell Stem Cell 27:125-136.e7. https://doi.org/ 10.1016/j.stem.2020.06.015

\section{Authors and Affiliations}

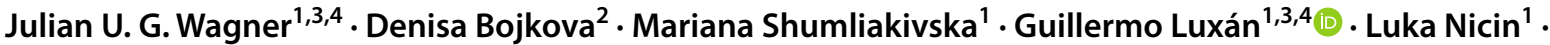 Galip S. Aslan ${ }^{1} \cdot$ Hendrik Milting ${ }^{5} \cdot$ Joshua D. Kandler ${ }^{2} \cdot$ Andreas Dendorfer $^{3,6}$. Andreas W. Heumueller, ${ }^{1,4}$. Ingrid Fleming ${ }^{3,4,7}$. Sofia-Iris Bibli ${ }^{3,4,7} \cdot$ Tobias Jakobi $^{8}$. Christoph Dieterich ${ }^{3,9}$. Andreas M. Zeiher ${ }^{3,4,10}$. Sandra Ciesek ${ }^{2,11,12} \cdot$ Jindrich Cinatl $^{2} \cdot$ Stefanie Dimmeler ${ }^{1,3,4} 4_{\mathbb{C}}$}

1 Institute for Cardiovascular Regeneration, Centre of Molecular Medicine, Goethe University Frankfurt, Theodor Stern Kai 7, 60590 Frankfurt, Germany

2 Institute of Medical Virology, University Frankfurt, Frankfurt, Germany

3 German Center for Cardiovascular Research (DZHK), Partner Site Rhein-Main, Frankfurt, Germany

4 Cardiopulmonary Institute (CPI), Frankfurt, Germany

5 Clinic for Thoracic and Cardiovascular Surgery, Bad Oeyenhausen, Germany

6 Walter-Brendel-Centre, Hospital of the Ludwig-Maximilians-University München, Munich, Germany

7 Institute for Vascular Signalling, Centre for Molecular Medicine, Goethe University, Frankfurt am Main, Germany
8 Department of Internal Medicine and the Center for Translational Cardiovascular Research, University of Arizona, 475 N. 5th Street, Phoenix, AZ 85004, USA

9 Klaus Tschira Institute for Integrative Computational Cardiology, University Hospital Heidelberg, Heidelberg, Germany

10 Department of Cardiology, University Frankfurt, Frankfurt, Germany

11 Fraunhofer Institute for Molecular Biology and Applied Ecology (IME), Branch Translational Medicine und Pharmacology, Frankfurt, Germany

12 German Centre for Infection Research (DZIF), External Partner Site Frankfurt, Frankfurt, Germany 